\title{
Development of a Competitiveness Enhancement Mechanism for National Car Production Enterprises
}

\author{
Antonina $\mathrm{Kuzub}^{1 * 1}$ \\ ${ }^{1}$ Ukrainian State University of Railway Transport, Department of Economics and Management of \\ Industrial and Commercial Business, 61050 Feerbach Square 7, Kharkov, Ukraine
}

\begin{abstract}
The article discusses the development and implementation of a competitiveness enhancement mechanism for national car production enterprises. It indicates the development stages of the competitiveness enhancement mechanism for car production enterprises. Four subsystems making the competitiveness enhancement mechanism for enterprises are distinguished: owners and investors, top management, lower level management and average executives. An algorithm of implementing the competitiveness enhancement mechanism for national car production enterprises has been developed.
\end{abstract}

\section{Introduction}

The development dynamics of the Ukrainian economy has been unstable over recent years showing different levels of industries readiness to cope with modern challenges, and being a consequence of a decrease in the investment and innovative activity, technological development and competitiveness of enterprises in the internal and external markets.

The Ukrainian economy can develop due to enhancement of car production enterprises' competitiveness. Enhancement of competitiveness of enterprise and products in the current economic context is a rather complex mechanism for the majority of car production enterprises due to the lack of effective methods covering the enterprise's business integrity.

The issue of car production enterprises' competitiveness enhancement can be resolved based on implementation of the competitiveness enhancement mechanism that is an effective tool to achieve national priorities and the basic principles of innovative and technological development of the Ukrainian economy.

The car production enterprises need well-developed and operating comprehensive tools so as to enhance their competitiveness that take into account branch specifics and current status of the industry, for further development of the Ukrainian economy. Therefore, functioning of the enhancement mechanism tools with a synergy effect is a precondition to reach the target competitiveness level.

\footnotetext{
* Corresponding author: njyz11@meta.ua
} 


\section{Analysis of the Latest Researches and Publications.}

Works of many foreign and Ukrainian scientists are concerned with research of the competitiveness enhancement mechanism, including those by V.I. Blonska, M. I. Ivanova, I. Ya. Kachmaryk, Ya.D. Klymenko, V.O Kovalenko, P.O. Kutsyk, R.L. Lupak, I.M. Pushkarchuk, P. Yu. Yatsus. However, despite a considerable number of scientific publications in the field, the car production enterprises have no such mechanism, and therefore the issue is still relevant.

\section{Statement of Purposes.}

The main objective hereof is to develop a competitiveness enhancement mechanism for national car production enterprises.

\section{Statement of Basic Materials.}

The competitiveness enhancement mechanism for car production enterprises is a set of functions, tools, means and methods, using which a manager influences the whole internal capacity of a car production enterprise, as well as controlled external environment parameters, in order to identify and implement its competitive advantages.

The development of a competitiveness enhancement mechanism for car production enterprises involves the following stages:

1) making a decision on scope and areas of enhancement of the reached competitiveness indicator of the enterprise under study. In practice, top managers take such decision in coordination with the Director of the enterprise, but an approach when a decision is made by each employee involved in the performance of works on competitiveness enhancement along with planning the achievement of this purpose within each department is deemed logically correct.

2) Determining external (taxes, loan interest rate, exchange rate, etc.) and internal (planning, management system, quality control, incentives, etc.) factors influencing specific competitiveness indicators and the weighted average competitiveness indicator. Identification of dependent (variable) and independent (non-variable) factors. Whereas competitiveness is always relative in time or space, the analysis of influence at meso and macro levels and changes forecast for the period beyond completion of competitiveness enhancement mechanism implementation are an important stage in the development of such mechanism. At this stage, it is necessary to collect, predict and systematize opportunities and risks of the national car production enterprises.

Determination and forecast of external impact on the competitiveness enhancement mechanism implementation make it possible to create a corporate strategy with due account for possible market changes. The work on analysis and forecast determines the future of the enterprise, allowing it to hold competitive positions in the long term.

In this regard, in order to hold competitive positions based on response time, it is required to designate the following actions as important for market forecast: market (competitors, prices, goods, quality) analysis; economic and political analysis (forecast of inflation, exchange and interest rates growth); resources availability analysis (forecast of availability and growth in prices for resources used in the production); human resources availability analysis (forecast of availability of human resources as per principal trade jobs).

3) Selection and justification of competitiveness enhancement tools are based on assessment of the enterprise's competitiveness, determination of opportunities and threats, as well as specification of indicators that need improvement. Justification of competitiveness 
enhancement tools is performed based on the relevance, need, opportunity and effectiveness of their use in order to improve competitiveness as per such area (indicator).

Identification of competitiveness enhancement tools makes it possible to list specific measures aimed at improvement of the car production enterprises' competitiveness. A set of competitiveness enhancement actions for car production enterprises based on changes in impact of tools ensuring the competitive position is a system of individual projects involving specific employees, budgets and plans.

4) Development of detailed plans for introduction of competitiveness enhancement actions by structural departments of the enterprise. A plan providing for detailed and specific functions, business processes, specific competitiveness enhancement resources is developed based on external and internal impact by each competitiveness enhancement area and its estimated indicator. As a result, the annual competitiveness enhancement plan represents a system of individual projects involving specific employees, budgets and plans. The specified "design department" (DD) exercises an important function in coordination of works within the enterprise.

5) Assessment of results of the competitiveness enhancement mechanism implementation in the short, medium and long terms. The key function of the DD at the final stage of the competitiveness enhancement involves assessment of cost efficiency of the competitiveness enhancement (to be performed upon introduction of each action under the general methodological principle of correlation between the result and the related expenses), as well as reassessment of the enterprise's competitive position with identification of profit and further implementation monitoring.

The competitiveness enhancement mechanism for a car production enterprise is represented in Figure 1.

The top managers and personnel should take decisions to increase the efficiency of the competitiveness enhancement mechanism by specific areas based on the logic of creation of such mechanism for national car production enterprises.

The competitiveness enhancement mechanism for car production enterprises consists of four subsystems: owners and investors, top management, lower level management and average executives.

The main task of the first subsystem involves formation of a strategic objective and desirable competitiveness level of an enterprise incorporated by its owners and investors. The competition strategy is developed and adopted at the top management level, using the strategic analysis tools and taking into account all possible impact factors. The lower level managers define tools for improvement of the enterprise's competitiveness by means of which the task and actions aimed to enhance the national car production enterprises' competitiveness are developed. At the final stage, the average executives take actions to enhance competitiveness of car production enterprises, approved by all above subsystems.

The author considers it necessary to take actions aimed at enhancement of the car production enterprises' competitiveness as follows: improvement of technical production standards; improvement of product competitiveness; decrease of expenses; improvement of management efficiency; improvement of marketing and sales management; diversification; innovations.

When developing actions aimed at competitiveness enhancement, it is essential to perform diagnostics of problems in the car production enterprise's management system. The quality of the enterprise's (or its divisions) management system at all levels is one of the major factors of the internal corporate environment influencing the competitive position, as well as understanding an accurate development strategy and tactics by employees, knowledge and observance of the existing business processes.

In order to ensure modern hi-tech infrastructure of the industrial complex, and in particular the car-production complex, and for development of the economy of Ukraine, in order to meet 


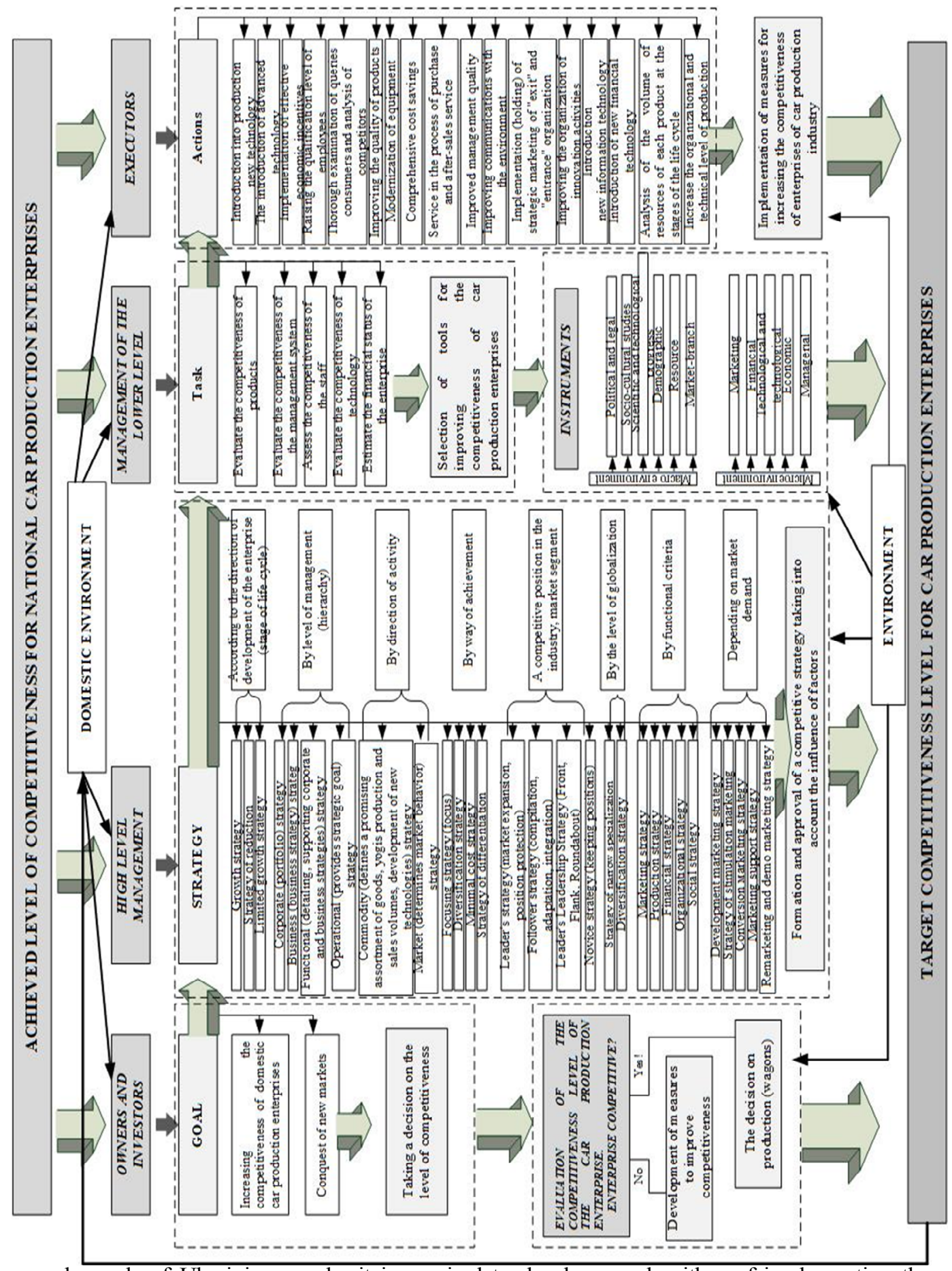

demands of Ukrainian people, it is required to develop an algorithm of implementing the competitiveness enhancement mechanism for national car production enterprises.

Fig. 1. Block diagram of the competitiveness enhancement mechanism for a car production enterprise. 
The algorithm of implementing the competitiveness enhancement mechanism for national car production enterprises includes elements to be implemented in the following order:

1 - Assessment of the enterprise's competitive status in each segment of the occupied market (in the context of enterprises, products and services). Such assessment is carried out using the standard technique involving selection of a reference object and comparison of indicators of the enterprise under study (products or service) with the enterprise taken as the reference object;

2 - identification and assessment of a competitiveness parameter (indicator) that needs improvement. This stage involves comparison of competitiveness indicators system of the reference enterprise with the indicators of the enterprise under study to identify indicators reducing/enhancing competitive status of such enterprise within the occupied marked segments;

3 - analysis of the competitiveness enhancement tools, selection of tool by each indicator that needs improvement.

At this stage, it is important to select a tool improving competitiveness, which can be used effectively at such enterprise. In the course of such analysis, it is essential to consider resource, organizational and administrative opportunities of the use of each tool capable to improve competitiveness;

4 - development of actions aimed to improve competitiveness and ranging them as per importance degree, taking into account external impact and internal environment of the enterprise. Organizational and technical actions, the priority of which depends on the current competitive status in the specific market segment are developed for the revealed system of competitiveness parameters that need improvement;

5 - development of a program for competitiveness enhancement of the enterprise for a planning period (year, six months, quarter). The competitiveness enhancement program of the enterprise for the specific planning period is based on the list of actions ranged as per importance degree. The period of actions planning is determined by the emergency measured aimed at competitiveness enhancement and resource restrictions: financial, material and organizational, etc.;

6 - management of each action within the developed competitiveness enhancement mechanism. At this stage, it is required to perform the following: to define areas of responsibility of managers and personnel of the enterprise in regard to competitiveness enhancement as per each parameter (indicator and/or action), taking into account the content of measures to be taken and the term of performance; to develop internal standard and legal documents (order, regulation, instruction, statute, etc) ensuring introduction of actions aimed at enhancement of the enterprise's competitiveness;

7 - introduction of the competitiveness enhancement mechanism at the enterprise. At this stage, it is essential to consider the following: degree of personnel readiness to implement the competitiveness enhancement program, need for preparation and retraining of the personnel for performance of the planned actions aimed competitiveness enhancement; level of possible resistance of personnel at implementation of the competitiveness enhancement program;

8 - assessment of the implemented competitiveness enhancement mechanism efficiency.

Adaptation of the algorithm for the competitive status of the car production enterprise will ensure further successful implementation and functioning of the competitiveness enhancement mechanism at national car production enterprises, giving an opportunity for development of the economy of Ukraine in general in order to meet demands of the Ukrainian people.

Monitoring of the competitiveness enhancement mechanism in actual practice of a car production enterprise should be accompanied by analytical and information support of the relevant services and departments performed under accurate management of the enterprise and with a frequency in order to reduce risks of decrease in competitiveness and economic efficiency. 
The efficiency of competitiveness enhancement mechanism implementation is reflected by indicators of the car production enterprise's economic activity, significantly improved as a result of competitiveness enhancement. Including: profitability of production and products; amount of profit; production cost; increase of the enterprise's market share.

\section{Conclusion.}

The technique of competitiveness enhancement mechanism development proposed herein by the author offers the possibility to resolve of the competitiveness issue systematically, providing the enterprise's management system with the tools for identification and realization of the enterprise's competitive advantages.

The competitiveness enhancement mechanism developed can be used at car production enterprises of any legal form or level as, due to correct selection of competitiveness enhancement tools, it is possible to consider specifics of any car production or industrial enterprise and develop an effective mechanism to enhance its competitiveness.

The technology of the competitiveness enhancement mechanism implementation can be applied in practice of national car-production enterprises in order to enhance their competitiveness and to foster the national economy development in general.

Therefore, in order to resolve the issue of the Ukrainian economy development, it is required to introduce the competitiveness enhancement mechanism for car-production enterprises in Ukraine using the author's algorithm of such mechanism implementation, which also have influence the development of the industrial complex and meeting the demand of the Ukrainian people.

\section{References}

1. Danko M.I., Dykan V.L., Kalinichenko L.L., Pidvyshchennya investytsiyno-innovatsiynoho potentsialu promyslovykh pidpryyemstv zaliznychnoho transportuvannya intehratsiynykh protsesiv. UkrSART, 167 (2010)

2. Panchenko S.V., Dykan V.L., Volovelska I.V., Maslova V.O., Upravlinnya biznesom. UkrSURT, 312 (2016)

3. Rail EXPO 2017, the strictly railroad-related international exhibition to be held for the first time in Ukraine [Electronic resource]. - URL: http://uprom.info/anons-podiy/vpershe-vukrayini-proyde-suto-zaliznichna-mizhnarodna-vistavka-rail-expo-2017/

4. International Specialized Exhibition Rail EXPO 2018 [Electronic resource]. - URL: https://railexpoua.com/

5. Kuzub A.V. Derzhava ta rehiony. Seriya: Ekonomika ta pidpryyemnytstvo, 3 (120), 90-98 (2018)

6. Kuzub A.V. Prichornomorski ekonomichni studiyi, 26, 10-15 (2018)

7. Kuzub A.V. The quality control system of domestic industrial companies of railway transport. Problems of systemic approach in the economy, 1 (63), 64-69 (2018)

8. Danko M.I., Dykan V.L., Yakimenko N.V., Zabezpechennya konkurentospromozhnosti promyslovykh pidpriyemstv $v$ uslovyyakh mizhnarodnoho transportnykh koridoriv, UkrSART, 169 (2008)

9. Tolstova A.V. The bulletin of transport and industry economics, 30, 97-102 (2010)

10. Dykan V.L., Zaiets A.P. The bulletin of transport and industry economics, 62 (SPECIAL

ISSUE), 297-305 (2018) 